(2) Open Access Full Text Article

\title{
Strongyloides stercoralis hyperinfection in a post-renal transplant patient
}

This article was published in the following Dove Press journal:

Clinical and Experimental Gastroenterology

29 November 2011

Number of times this article has been viewed

Hussain Issa'

Mohamad A Aljama'

Ahmed $\mathrm{H} \mathrm{Al-Salem}{ }^{2}$

'Department of Internal Medicine, King Fahad Specialist Hospital,

${ }^{2}$ Department of Pediatric Surgery, Maternity and Children Hospital,

Dammam, Saudi Arabia
Correspondence: Ahmed H Al-Salem PO Box 61015, Qatif 31911, Saudi Arabia Tel +966505818009

Fax +96638630009

Email ahsalsalem@hotmail.com
Abstract: Strongyloides stercoralis is an intestinal nematode that is able to infect the host tissue and persist asymptomatic for many years through autoinfection. It causes life-threatening hyperinfection in immunocompromised hosts. This report describes a rare case of strongyloidiasis in a 40-year-old male following renal transplant, which was diagnosed by colonoscopic biopsy. The literature on the subject is also reviewed.

Keywords: Strongyloides stercoralis, hyperinfection, immunosuppression

\section{Introduction}

Strongyloides stercoralis is a soil-transmitted intestinal nematode that has been estimated to infect at least 60 million people, especially in tropical and subtropical regions. ${ }^{1-4}$ Many infected patients are completely asymptomatic and the infection can remain undetected for years. The uncomplicated intestinal form of the disease usually produces nonspecific abdominal symptoms with or without mild sporadic diarrhea. Strongyloides infection, in contrast, has been described in a variety of conditions including those on immunosuppressant therapy, post-transplantation, hematologic malignant disease, human immunodeficiency virus, malnutrition, diabetes mellitus, rheumatoid arthritis, chronic renal failure, hypogammaglobulinemia, and chronic alcohol consumption. ${ }^{5-18}$ In these patients, hyperinfection can occur, which, if not recognized and treated aggressively, can result in mortality rates as high as $87 \%{ }^{1,19}$ In humans, S. stercoralis infestation most commonly involves the upper small intestine and the usual clinical presentation is nonspecific and vague and the infestation can mimic several other conditions such as inflammatory bowel disease. Given the increasing numbers of immunocompromised individuals, physicians caring for these patients should be aware of this potential and sometimes fatal complication. This report describes a 40 -year-old male who underwent renal transplant and developed colonic hyperinfection with $S$. stercoralis.

\section{Case report}

In 2008, a 40-year-old male was diagnosed with end-stage renal disease of unknown etiology and was started on regular hemodialysis. During this time he was also found to be hypertensive and was treated with antihypertensive medications. In February 2010, he underwent renal transplant after induction with antithymoglobulin. Four months after the operation, he started to complain of severe nausea, vomiting, and significant loss of weight. At the time of presentation, he was maintained on: tacrolimus $1 \mathrm{mg}$ orally twice daily, mycophenolate mofetil $500 \mathrm{mg}$ orally three times daily, prednisolone $5 \mathrm{mg}$ orally 
once daily, esomeprazole $40 \mathrm{mg}$ orally once daily, bisoprolol $5 \mathrm{mg}$ orally once daily, methyldopa $500 \mathrm{mg}$ orally three times daily, and calcitriol and cotrimoxazole $480 \mathrm{mg}$ orally twice daily. His examination was normal apart from a palpable transplanted kidney in the right iliac fossa. Investigations showed a white blood cell count of $6.19 \times 10^{9} / \mathrm{L}$; neutrophils $5.37 \times 10^{9} / \mathrm{L}(87.1 \%)$; eosinophils $2.5 \times 10^{9} / \mathrm{L}(0.15 \%)$; hemoglobin $10.4 \mathrm{~g} / \mathrm{dL}$; hematocrit $33.2 \%$, with a mean cell volume of 80.1 and a mean cell hemoglobin of 26.2. His platelet count was $301 \times 10^{9} / \mathrm{L}$, renal panel showed creatinine of $145 \mu \mathrm{mol} / \mathrm{L}$, blood urea nitrogen $6.3 \mathrm{mmol} / \mathrm{L}$, sodium $128 \mathrm{mmol} / \mathrm{L}$, and potassium $3.7 \mathrm{mmol} / \mathrm{L}$. He underwent upper gastrointestinal endoscopy, which showed mild gastritis, and the biopsy was negative for Helicobacter pylori. As there was no improvement on proton pump inhibitors and prokinetics, colonoscopy was performed. This revealed aphthoid-like ulcers at the rectum and rectosigmoid areas. The ascending colon showed mucosal segments with granularity, pin-point ulceration with fibrin deposits (see Figure 1), and bleeding on touch. The findings were suggestive of inflammatory bowel disease. However, the biopsy revealed focal nonspecific inflammation, with larva-like parasites spotted on rectal biopsy (see Figure 2). Fecal examination confirmed the presence of a large number of $S$. stercoralis. He was started on a 10-day course of albendazole $400 \mathrm{mg}$ orally twice daily. His symptoms subsided and he gradually started gaining weight. Fecal examinations 2 and 4 weeks after the initiation of therapy were normal.

\section{Discussion}

S. stercoralis is an intestinal nematode of humans. Although most infected individuals are asymptomatic, ${ }^{19,20}$ S. stercoralis is capable of causing a fulminant illness that is often fatal if not recognized and treated. This is seen in certain conditions associated with a decrease in host immunity, including immunosuppressive therapy (particularly the use of glucocorticoids), hematological malignancies, bone marrow and renal transplants, human T-cell lymphotropic virus
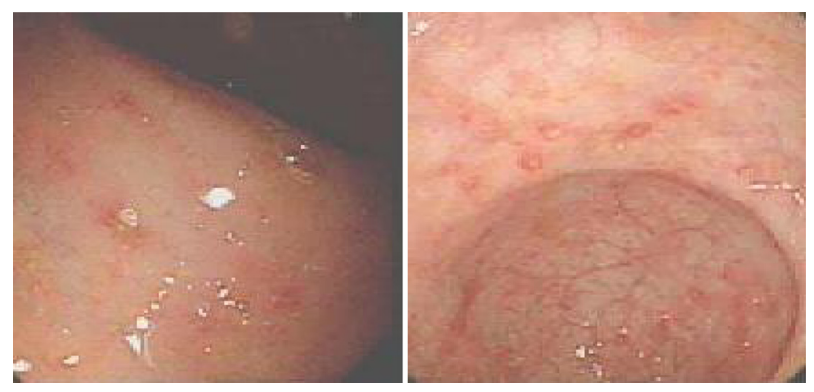

Figure I Colonoscopic picture showing aphthoid-like ulcers, granularity, and pin-point ulceration with fibrin deposits.

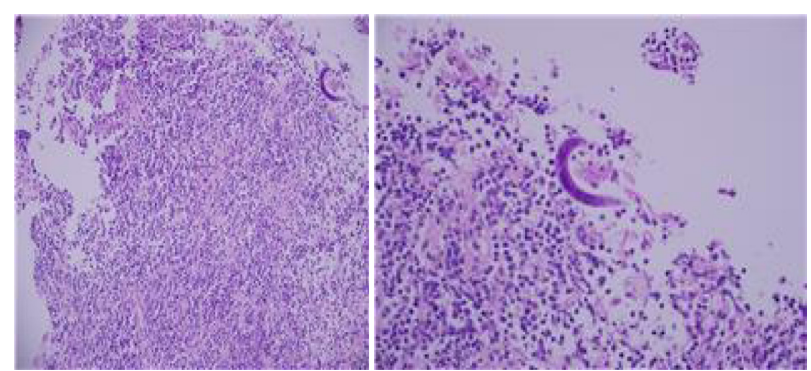

Figure 2 Colonic biopsy showing focal nonspecific inflammation with Strongyloides stercoralis larvae.

type 1 infection, human immunodeficiency virus infection, hypogammaglobulinemia, and malnutrition. ${ }^{5-18}$ Although various immunocompromising conditions have been associated with hyperinfection, steroids and human T-cell lymphotropic virus type 1 infection are the most consistent. In these conditions $S$. stercoralis causes hyperinfection. ${ }^{1,19}$ The patient discussed had a $S$. stercoralis hyperinfection following renal transplant. Of interest is that the majority of cases of hyperinfection with $S$. stercoralis that have occurred following organ transplant were seen in patients following renal transplant and most of these cases seem to have been precipitated by increased glucocorticoid doses in response to rejection. ${ }^{8,17}$ The authors' patient did not show signs of rejection, but he was on glucocorticoid therapy and this probably contributed to the development of superinfection. Given the increasing numbers of immunocompromised patients throughout the world, this calls for a closer evaluation and observation of all conditions under which $S$. stercoralis infection becomes dangerous. This is of paramount importance to physicians caring for these patients, as early identification and treatment of those at risk is likely to decrease the morbidity and mortality associated with $S$. stercoralis superinfection.

S. stercoralis commonly causes gastrointestinal symptoms that are nonspecific and easily attributed to other diseases. This was the case in the patient discussed, who was complaining of nausea and vomiting only; the striking and alarming feature was the sudden and significant weight loss. This called for further investigation including colonoscopy, which showed features suggestive of inflammatory bowel disease. The diagnosis of $S$. stercoralis infection was made on colonic biopsy and subsequently on fecal examination. The definitive diagnosis of $S$. stercoralis infection depends on the demonstration of larvae in the feces or duodenal fluid. In uncomplicated cases, the intestinal worm load is low and larval output is minimal. A single fecal examination thus fails to detect larvae in up to $70 \%$ of cases. ${ }^{21}$ Repeated fecal examinations increase the sensitivity of detection of $S$. stercoralis infection. ${ }^{22}$ 
In immunocompromised patients, the autoinfective cycle of $S$. stercoralis can become amplified into a potentially fatal hyperinfection syndrome, characterized by increased numbers of infective filariform larvae in the feces.

Strongyloidiasis is a curable disease and early diagnosis and appropriate therapy with anthelmintics can reduce morbidity and mortality. ${ }^{23-27}$ Ivermectin, when compared with albendazole and thiabendazole, shows similar or better rates of larval clearance from feces with similar side effects but is much better tolerated and has become the treatment of choice. An important point which must be considered is the fact that hyperinfections are often complicated by infections caused by gut flora that gain access to extra-intestinal sites, presumably through gut ulcers induced by the filariform larvae. Gut flora can include Escherichia coli, Klebsiella pneumoniae, Proteus mirabilis, Pseudomonas spp, Enterococcus faecalis, coagulase-negative staphylococci, Streptococcus bovis, and Streptococcus pneumoniae. Patients on immunosuppressive therapy may also develop systemic candidemia in addition to enteric Gram-negative infections.

\section{Disclosure}

The authors report no conflicts of interest in this work.

\section{References}

1. Altintop A, Cakar B, Hokelek M, Bektas A, Yildiz L, Karaoglanoglu M. Strongyloides stercoralis hyperinfection in a patient with rheumatoid arthritis and bronchial asthma: a case report. Ann Clin Microbiol Antimicrob. 2010;9:27.

2. Rowlands PC, Speechly-Dick ME, Grech P. Strongyloidiasis of the colon. Br J Radiol. 1990;63(752):650-652.

3. AlSamman M, Haque S, Long JD. Strongyloidiasis colitis: a case report and review of the literature. J Clin Gastroenterol. 1999;28(1):77-80.

4. Nam SC, Han MH, Kim YS, Kum YS, Suh IS, Bae HI. Two cases of strongyloidiasis diagnosed by colonoscopic biopsy. Korean Journal of Pathology. 2007;41:343-346.

5. Adam M, Morgan O, Persaud C, Gibbs WN. Hyperinfection syndrome with Strongyloides stercoralis in malignant lymphoma. $\mathrm{Br}$ Med $\mathrm{J}$. 1973;1(5848):264-266.

6. Armignacco O, Capecchi A, De Mori P, Grillo LR. Strongyloides stercoralis hyperinfection and the acquired immunodeficiency syndrome. Am J Med. 1989;86(2):258.

7. Brandt de Oliveira R, Voltarelli JC, Meneghelli UG. Severe strongyloidiasis associated with hypogammaglobulinaemia. Parasite Immunol. 1981;3(2):165-169.

8. Briner J, Eckert J, Frei D, Largiader F, Binswanger U, Blumberg A. Strongyloidiasis following kidney transplantation. Schweiz Med Wochenschr. 1978;108(42):1632-1637. German.

Clinical and Experimental Gastroenterology

\section{Publish your work in this journal}

Clinical and Experimental Gastroenterology is an international, peerreviewed, open access journal, publishing all aspects of gastroenterology in the clinic and laboratory, including: Pathology, pathophysiology of gastrointestinal disease; Investigation and treatment of gastointestinal disease; Pharmacology of drugs used in the alimentary tract;
9. Buss DH. Strongyloides stercoralis infection complicating granulocytic leukemia. N C Med J. 1971;32(7):269-274.

10. Cahill KM, Shevchuk M. Fulminant, systemic strongyloidiasis in AIDS. Ann Trop Med Parasitol. 1996;90(3):313-318.

11. Celedon JC, Mathur-Wagh U, Fox J, Garcia R, Wiest PM. Systemic strongyloidiasis in patients infected with the human immunodeficiency virus. A report of 3 cases and review of the literature. Medicine (Baltimore). 1994;73(5):256-263.

12. Cohen J, Spry CJ. Strongyloides stercoralis infection and small intestinal lymphoma. Parasite Immunol. 1979;1(2):167-178.

13. Coovadia YM, Rajput MC, Bhana RH. Disseminated strongyloidiasis in a diabetic patient. Trop Geogr Med. 1993;45(4):179-180.

14. Daubenton JD, Buys HA, Hartley PS. Disseminated strongyloidiasis in a child with lymphoblastic lymphoma. J Pediatr Hematol Oncol. 1998;20(3):260-263.

15. Debussche X, Toublanc M, Camillieri JP, Assan R. Overwhelming strongyloidiasis in a diabetic patient following adrenocorticotropin treatment and keto-acidosis. Diabetes Metab. 1988;14(3):294-298.

16. de Oliveira LC, Ribeiro CT, Mendes Dde M, Oliveira TC, Costa-Cruz JM. Frequency of Strongyloides stercoralis infection in alcoholics. Mem Inst Oswaldo Cruz. 2002;97(1):119-121.

17. DeVault GA Jr, King JW, Rohr MS, Landreneau MD, Brown ST, McDonald JC. Opportunistic infections with Strongyloides stercoralis in renal transplantation. Rev Infect Dis. 1990;12(4):653-671.

18. Gotuzzo E, Terashima A, Alvarez H, et al. Strongyloides stercoralis hyperinfection associated with human $\mathrm{T}$ cell lymphotropic virus type-1 infection in Peru. Am J Trop Med Hyg. 1990;60(1):146-149.

19. Siddiqui AA, Berk SL. Diagnosis of Strongyloides stercoralis infection. Clin Infect Dis. 2001;33(7):1040-1047.

20. Kishimoto K, Hokama A, Hirata T, et al. Endoscopic and histopathological study on the duodenum of Strongyloides stercoralis hyperinfection. World J Gastroenterol. 2008;14(11):1768-1773.

21. Koosha S, Fesharaki M, Rokni MB. Comparison of enzyme-linked immunosorbent assay and indirect immunofluorescence assay in the diagnosis of human strongyloidiasis. Indian J Gastroenterol. 2004;23(6):214-216.

22. Hirata T, Nakamura H, Kinjo N, et al. Increased detection rate of Strongyloides stercoralis by repeated stool examinations using the agar plate culture method. Am J Trop Med Hyg. 2007;77(4):683-684.

23. Grove DI. Treatment of strongyloidiasis with thiabendazole: an analysis of toxicity and effectiveness. Trans R Soc Trop Med Hyg. 1982;76(1): 114-118.

24. Datry A, Hilmarsdottir I, Mayorga-Sagastume R, et al. Treatment of Strongyloides stercoralis infection with ivermectin compared with albendazole: results of an open study of 60 cases. Trans $R$ Soc Trop Med Hyg. 1994;88(3):344-345.

25. Marti H, Haji HJ, Savioli L, et al. A comparative trial of a single-dose ivermectin versus three days of albendazole for treatment of Strongyloides stercoralis and other soil-transmitted helminth infections in children. Am J Trop Med Hyg. 1996;55(5):477-481.

26. Nandy A, Addy M, Patra P, Bandyopashyay AK. Fulminating strongyloidiasis complicating Indian kala-azar. Trop Geogr Med. 1995;47(3): 139-141.

27. Torres JR, Isturiz R, Murillo J, Guzman M, Contreras R. Efficacy of ivermectin in the treatment of strongyloidiasis complicating AIDS. Clin Infect Dis. 1993;17(5):900-902.

\footnotetext{
Submit your manuscript here: http://www.dovepress.com/clinical-and-experimental-gastroenterology-journal
}

Dovepress

Immunology/genetics/genomics related to gastrointestinal disease. This journal is indexed on CAS. The manuscript management system is completely online and includes a very quick and fair peer-review system. Visit http://www.dovepress.com/testimonials.php to read real quotes from published authors. 